\title{
AN ANALYSIS OF CHILDHOOD GOOD VALUES IN C.S.LEWIS'S NOVEL THE VOYAGE OF THE DAWN TREADER
}

\author{
Panisia Julita \\ University of Bengkulu \\ nisapanisia@gmail.com \\ Mukhrizal. \\ University of Bengkulu \\ Indah Damayanti \\ University of Bengkulu
}

\begin{abstract}
This research aimed to find out childhood good values in C.S. Lewis's Novel The Voyage of the Dawn Treader and their implications for education. The research was carried out by employing a descriptive qualitative method of library research. The data were collected by reading and analyzing the novel thoroughly. The results of the study revealed that there were several childhood good values in The Voyage of the Dawn Treader novel such as obedience, honesty, imagination, pleasure, kinship, bravery, regret, intelligence, helpfulness, forgiveness, and friendship. Nevertheless, there were also some bad values namely annoyance, selfishness, and greediness. The good values in the novel were basically universal, so they were congruent with the 2013 Curriculum in term of spiritual and social competencies. Thus, they implied that they can be used as teaching materials and source of references to teach both competencies.
\end{abstract}

Key Words : Childhood, Good Values, Novel 


\section{INTRODUCTION}

Literature is a form of creative art using language as the medium and the object of its work is human and his life. Literature is a medium through which a person can convey his or her ideas or protest against different norms of society. Literature is a social institution and it cannot be separated from the society because literature is the product of an author who is the member of the society.

In every part of the world, literature has been more or less, the mirror of society because it gives an image, but the image is not necessarily a true image. Literature tends to focus on the reflection of the society. In literature, we find stories designed to portray human life and action through some characters who present what people think, say, and do in society. Nevertheless, the most realistic forms of literature are the stories and novels.

Novel is an imitation of the real human life. It is related with the function of literary work to entertain and give much inspiration. A novel is one of genres of literary works which presents in detail the enlargement of character, or complicate social circumstances, or a relation between many personalities. It is compose of many different phenomenons and intricate relationships surround by a few people in the novel (Stanton,1965:44).

The way of life and values both of them are the one of substance of culture in the society.Values are beliefs about what is right and what is important in life. It means the values are something good, considered something that very important of society. The stories and the novels particularly deal with the problem of social, economics, politics, or education.

Values in education is reflected into children literature. Hunt, (2003:33) states that since the 15 th century, a large quantity of literature, often with a moral or religious message, has been aimed specifically at children. There are many children values that can be found in the literature especially novel. In the children literature, we can analyze the childhood values in the novel that is represented.

According to Stewig, (1988:12) children literature is good quality trade books for children from birth to adolescence, covering topics of relevance and interests to children of those ages, through prose and poetry, fiction, and nonfiction. Therefore, the best children's book offers readers enjoyment as well as memorable characters and situation and valuable insight the human condition.

One of children literature is found in C.S.Lewis's novel entitled The Voyage of the Dawn Treader. The author delivers that message by the story happening with dialogues among the characters and the story that is represented in the novel. There are many aspects such as intrinsic and extrinsic elements that help the reader to get the meaning in the novel and the storyline.

The Voyage of the Dawn Treader is a high fantasy novel for children by C.S Lewis published by Geoffrey Bles in 1952. It was the third published of seven novels in the Chronicle of Narnia series (19501956). Macmillan US published an American edition that were retained in the US until 1994. This novel has been adapted and filmed as four episodes of BBC television series in 1989 and as a featured film in 2010.

The Voyage of the Dawn Treader is different from another two novels before. In the two novels before, the enemy was created to be real icon, such as The White Witch in the first novel and Lord Miraz in the second novel. However, in this third novel the enemy was not real. C.S.Lewis lead the characters and the readers to enter the existential area. The enemy 
became unpredictable and confused. The Voyage of the Dawn Treader lead us to differentiate between 'black and white' and 'good and bad'.

Values in the novel usually occurs in many ways. The readers need to read it very carefully and analyze it deeper to take the education behind it. Moreover, an author can communicate with the readers of a literary works if they can understand what the author wants to send. The author expresses his or her feeling, thought, ideas, or arguments about the social issues by writing those issuess in a form of literary works.

Hence, it is needed to analyze the values around children in The Voyage of the Dawn Treader Novel to take more education behind it and then can know the implications for education. From the reasons above both because of how rich the ideas and values of the novel and the great author who delivered it, the research entitled "An Analysis of Childhood Good Values in C.S.Lewis's Novel The Voyage of the Dawn Treader" was needed to be done.

This research had two research questions were "What are the childhood good values in The Voyage of the Dawn Treader Novel?" and "What are the implications of childhood good values in The Voyage of the Dawn Treader novel for education?"

The researcher expected this research will give some influences both academically and practically, and the further researchers as well.

\section{METHOD}

This research was library research and used qualitative approach, qualitative in a natural phenomena where the researcher works as the primary instrument of data collection that compiles words, analyzes then inductively, concerns with the meaning of participants, and describes an expressive language processes (Creswell, 1998).

Concerning with the objective of the study, the method that had been used in this research was descriptive qualitative method. It means this research described the childhood values in The Voyage of the Dawn Treader Novel. Descriptive method is a method for solving actual problem through searching the data, arranging the data, classifying the data, and interpreting the data in the systematic way (Zuriah:2009).

In qualitative research, it does not use population term but spread names social situation that consist of subject or object of the study. The object of this research was The Voyage of the Dawn Treader novel by Clive Staples Lewis. This novel is a high fantasy novel for children published by Geoffrey Bles in 1952. It was the third published of seven novels in The Chronicle of Narnia (1950-1956). Lewis dedicated the book to Geoffrey Corbett. $\mathrm{He}$ is the foster-son of Owen Barfield, the friend, teacher, adviser, and trustee of Lewis. The Voyage of the Dawn Treader consisted of 223 pages and 52.038 words in the first edition and 493 pages in the Ebook version.

In collecting data, the researcher will use documentation method, which is According to Arikunto (1998), documentation method is searching data about things or variable in the form of notes, transcript, book, newspaper, magazines, meeting notes, ledger, agenda, and any other written media.

In using this technique, the researcher as the key instrument (Sugiyono,2006:251) to read carefully in several times, analyze, and interpret about the data sources that the literary works in this case The Voyage of the Dawn Treader novel in order to obtain the desired data. Moreover, to support the 
data the researcher added other information, it can be some articles or review about that novel. The results of the data source were written for use in prepare the research report in accordance with the aims and objectives to be achieved.

According to Johnson \& Christensen (2004:162), data analysis is the process whereby researcher systematically search and arrange their data in order to increase their understanding of the data. Data analysis in qualitative research is the process and the preparation are systematically obtained from the technical documentation, by way of organizing data into categories, describe into the units, synthesize, organize into a pattern, choose what is important and that will be studied and make conclusions invitation of words or phrases separated by category for the conclusion (Arikunto, 1998).

The analysis was focused on the values that have been brought by the children characters and it catagorized as childhood values. The researcher needed to catagorize the characters based on their age and chose whether it was childhood values or not. Then, the researcher examined the dialogue and the story as the citation to prove the data finding. Next, it was needed to analyze the implications of the values for education and link it on the relation of values and education theories and the 2013 Curriculum.

There were some steps the researcher have done in cunducting this research. The procedures as follow :

1. Reading The Voyage of the Dawn Treader novel several times carefully.

2. Finding the children characters in The Voyage of the Dawn Treader novel.

3. Finding the childhood values in The Voyage of the Dawn Treader novel.
4. Examining the values by bolding a phrase in the dialogues or story that considered as some of childhood values.

5. Analyzing the implications of childhood good values for education and link it on the relation of values and education theories.

6. Searching the articles or review about The 2013 Curriculum in the internet and other sources to support the analyzing the implications.

7. Making a conclusion of the results.

\section{RESULTS AND DISCUSSION}

\section{Results}

1. Childhood Values

After reading The Voyage of the Dawn Treader novel, the researcher found several childhood values. There are good values and bad values. The good values are as follows,

\section{a. Obedience}

Obedience is a compliance with an order, request, or law, or submission to another authority (Oxford Living Dictionary). Obedience in this novel was implemented by obeying The Pavensie's parents orders when they should stayed with Uncle Harold and Aunt Alberta. Mr. and Mrs. Pavensie was live in London, they have four children. One day, Mr. Pavensie got a job lecturing in America for sixteen weeks, and Mrs. Pavensie accompanied him to America.

While the eldest one, Peter prepared for his exam and he stayed and coached by Professor Kirke whose these four children had wonderful adventures long ago in the war years. The second one was Susan, she was ready to marry, and her mother sends her far trip to America so, she would get a proper husband. It would spend much money if they take the other two Edmund and Lucy. Hence, Mr. and Mrs. Pavensie entrusted Edmund and Lucy 
to stay with Uncle Harold and Aunt Alberta's house during their trip. Ed and Lucy did not want to stay there because, there was their cousin Eustace who liked bossing and bullying. One for sure, Eustace disliked his cousins. Although from the deep of their heart Edmund and Lucy did not want to stay, they were considering these several condition and decided to obey to stay in Uncle Harold's house. The obedience value was illustrated in the following quote.

"Edmund and Lucy did not at all want to come and stay with Uncle Harold and Aunt Alberta. Nevertheless, it really could not be helped. Peter was working very hard for an exam and he was to spend the holidays being coached by old Professor Kirke in whose house these four children had had wonderful adventures long ago in the war years. If he had still been in that house, he would have had them all to stay. Nevertheless, he had somehow become poor since the old days and was living in a small cottage with only one bedroom to spare. It would have cost too much money to take the other three all to America, and Susan had gone. Grown-ups thought her the pretty one of the family and she was no good at school work (though otherwise very old for her age) and Mother said she "would get far more out of a trip to America than the youngsters" (Lewis, 2014:910)

\section{b. Honesty}

Honest means saying exactly what they mean without trying to hide feelings, opinions, or facts. In addition, Honesty is the quality of being honest (Oxford Advanced Learner's Dictionary).

Lucy was trying to tell the truth that Narnia was not a rhyme when Eustace came and teased them it was just a limerick. Although Edmund forbid her to response all of Eustace words, because he knew that Eustace just annoyed them. Actually, Lucy can ignore what Eustace said such what Edmund suggested to do or told that Narnia was just an imagination, however Lucy chose to be honest, as stated on following passage.

"Even looking is better than nothing," said Lucy. "And she is such a very Narnian ship." "Still playing your old game?" said Eustace Clarence, who had been listening outside the door and now came grinning into the room. Last year, when he had been staying with the Pevensies, he had managed to hear them all talking of Narnia and he loved teasing them about it. He thought of course that they were making it all up; and as he was far too stupid to make anything up himself, he did not approve of that. "You're not wanted here," said Edmund curtly. "I'm trying to think of a limerick," said Eustace. "Something like this: "Some kids who played games about Narnia Got gradually balmier and balmier-" "Well, Narnia and balmier don't rhyme, to begin with," said Lucy." (Lewis, 2014:14-16)

\section{c. Imagintion}

Imagination is the action of forming new ideas, or images or concepts of external objects not present to the senses (Oxford Living Dictionary). This values was stated when Lucy, Edmund, and Eustace were looking at the picture on the wall.

The picture on the wall was the picture of a ship sailing nearly straight, which, run up on the top of one glorious blue wave. Suddenly, the water seemed to move. As we know that in the reality, there is no moving wave on the picture however, the imagination of Lucy showed that, while Edmund and Eustace could not 
see that. This situation was stated on following citation.

"It's a rotten picture," said Eustace. "You won't see it if you step outside," said Edmund. "Why do you like it?" said Eustace to Lucy. "Well, for one thing," said Lucy, "I like it because the ship looks as if it was really moving. In addition, the water looks as if it was wet. And the waves look as if they were really going up and down." (Lewis, 2014:17-18)

\section{d. Pleasure}

Pleasure is feeling of happy satisfaction and enjoyment (Oxford Living Dictionary). It includes happiness, entertainment, enjoyment, ecstasy and euphoria. Caspian told to Edmund and Lucy that $\mathrm{He}$ and other ship members were going to find seven missing Lords. Suddenly, Edmund said that he agreed. Although he was had, no idea how far they had to go or what kind of struggle they will face. Edmund just very enthusiast and satisfied to join the adventure. These statements were illustrated on following citation.

"As high as my spirit," it said. "Though perhaps as small as my stature. Why should we not come to the very eastern end of the world? And what might we find there? I expect to find Aslan's own country. It is always from the east, across the sea, that the great Lion comes to us." "I say, that is an idea," said Edmund in an awed voice." (Lewis, 2014:41)

\section{e. Kinship}

Kinship is a bond of love and affection in a family that could be affection between husband and wife or parents to children, children to his parents also among the relatives (Fajar, 2017). Loving, caring and the willingness to sacrifice for his/her family are the behavior that shown on kinship value.
In this case, Lucy was very care to his cousin Eustace. Lucy worried about Eustace condition of seasickness because after they arrived at the Dawn Treader, Eustace was still staying on the cabin. Although Eustace was always bullying her and Edmund, Lucy really cares about him because he was their family after all. Lucy decided see Eustace condition and give him some delicious food, as stated in the following quote.

"Who's that?" said Eustace irritably. "Send him away. His voice goes through my head." "I've brought you something that will make you feel better, Eustace," said Lucy. "Oh, go away and leave me alone," growled Eustace." (Lewis, 2014:52)

\section{f. Bravery}

Being brave means to have a steady heart and a sense of confidence in dealing the danger and trouble This value was as performed by the figure of Lucy in the Island of the voices. The invisible people asked Lucy to go to Magician house and broke the spell therefore, they will visible again. If Lucy did not want, they will fight Lucy and others. Lucy thought that no other choices because they were invisible enemy and it was hard to fight with enemy that they could not see. It was needed a brave action because Lucy was going to come to the Magician house alone and based on the invisible people story, the Magician was very terrified. Lucy was brave herself as described in the following statement.

"All right, then, I'll do it," said Lucy. "No," she said, turning to the others, "don't try to stop me. Can't you see it is no use? There are dozens of them there. We can't fight them. And the other way there is a chance. "But a magician!" said Caspian. "I know," said Lucy. "But he mayn't be as bad as they 
make out. Don't you get the idea that these people are not very brave?" (Lewis, 2014:281)

\section{g. Regret}

Regret means a feeling of sadness or disappointment that you have because of something that has happened or something that you have done or not done (Oxford Dictionary, 2015). Eustace realized that he was turn into a dragon because of his greediness and selfishness. At that moment, he was disappointed that even for the first time he arrived in the Dawn Treader he was never be a good friend for the crew especially Lucy and Reepicheep who always very kind to him.

He began wondering that felt lonely, he wanted to be a friend who can talk, and laugh and share things as well with others as a human. He realized the others were not fiends as he was always expected before. Eustace was really regret about all the bad acts he was done and deep on his heart he promised would be a good person if he could turn back into human. Eustace regret stated on following statement.

"But the moment he thought this he realized that he didn't want to. He wanted to be friends. He wanted to get back among humans, talk, and laugh and share things. He realized that he was a monster cut off from the completely human race. An appalling loneliness came over him. He began to see that the others had not really been fiends at all. He began to wonder if he himself had been such a nice person as he had always supposed. He longed for their voices." (Lewis, 2014:177-178)

h. Intelligence

Intelligence is the ability to learn, understand, and think in a logical way about things (Oxford Dictionary, 2015).
When Caspian, Edmund, Eustace, Lucy and Reepicheep went to the cave. They were found a helmet, a dagger, and a few coins and they investigated that was one of seven missing lords. However, they were confused about how the lord was killed except Edmund. He logically thought that the lord was not killed in a fight or by a wild animal. If the lord was killed in a fight, there must not be armor there. It did not make sense if the enemy took the body and not the armor. In addition, it did not make sense if the lord was killed by a wild animal because there was no animal that clever enough to take off the human shirt. Until, they realized that the lord was fallen into a pool, which turn things into gold.

"Look here," he said, "there's something very fishy about this. He can't have been killed in a fight."

"Why not?" asked Caspian. "No bones," said Edmund. "An enemy might take the armor and leave the body. But who ever heard of a chap who'd won a fight carrying away the body and leaving the armor?"

"Perhaps he was killed by a wild animal," Lucy suggested. "It'd be a clever animal," said Edmund, "that would take a man's mail shirt off." (Lewis, 2014:.241-242)

\section{i. Helpfulness}

Helping each other is the basic principle in social life because a man cannot live without others. Helping could occur because of the mutual benefits of a helper and who is helped or it could be because of the sincerity of rescuers to help others (Fajar, 2015).

It is as did by Lucy when seeing dragon's sore leg. Lucy looked its leg, which was sore and swollen with the golden bracelet. She was running to cure its leg with her healing water without paying attention to her safety anymore. 
Every ship members worried about her, they thought that perhaps it was liar dragon and it could endanger their little queen. It was shown that Lucy was very helpful even to the animal that could be injured her. This values as stated on following statement as follow,

"Oh look," said Lucy, "there's something wrong with its leg. The poor thing-that's probably what it was crying about. Perhaps it came to us to be cured like in Androcles and the lion." "Be careful, Lucy," said Caspian. "It's a very clever dragon but it may be a liar." Lucy had, however, already run forward, followed by Reepicheep, as fast as his short legs could carry him, and then of course the boys and Drinian came, too. "Show me your poor paw," said Lucy, "I might be able to cure it." (Lewis, 2014:187-188)

\section{j. Forgiveness}

Forgiveness is the act of forgiving somebody or the willingness to forgive somebody, (Oxford Dictionary: 2015). This action was illustrated through Eustace and Edmund. Eustace had been turn into human again; he was regret and realized that he had done such very bad things to Edmund, Lucy, also the whole ship members. Eustace told to Edmund all of his feelings and asked the forgiveness, Edmund said that what Eustace had done was not as bad as what he had done on the four Pavensies first trip to Narnia.

"And by the way, I'd like to apologize. I'm afraid I've been pretty beastly." "That's all right," said Edmund. "Between us, you haven't been as bad as I was on my first trip to Narnia. You were only an ass, but I was a traitor." (Lewis, 2014:214)

\section{k. Friendship}

Friendship is a relationship between friends, includes a close, lasting, and lifelong friendship (Oxford Dictionary, 2015). Friendship is a bond between people who trust each other and help each other to face problems.

In the Ramandu Island, three sleepers were three of seven missing lords. The ship members asked to stay in the ship rather than waiting the three sleepers in the Aslan table because they thought that must be danger to stay there along night. However, Reepicheep stated that it would stay there until sunrise. Reepicheep was just a mouse but it has been their friend. Hence, Edmund, Caspian, Lucy, and Eustace decided to accompany Reepicheep and asked the other ship members to rest in the Dawn Treader. The friendship was stated in the following excerpt.

"I am entirely of King Edmund's opinion," said Reepicheep, "as far as concerns the ship's company in general. But I myself will sit at this table till sunrise." "Why on earth?" said Eustace. "Because," said the Mouse, "this is a very great adventure, and no danger seems to me as great as that of knowing when I get back to Narnia that I left a mystery behind me through fear." "I'll stay with you, Reep," said Edmund. "And I too," said Caspian. "And me," said Lucy. And then Eustace volunteered also." (Lewis, 2014:387-388)

Beside the good values, the researcher found the bad values as well. Those bad ones are as follows,

\section{a. Annoyance}

Annoy is irritate someone or making someone a little angry (Oxford Dictionary, 2015). It was shown on Eustace action 
when Edmund and Lucy came to stay in his house.

Eustace disliked his cousins the four Pavensies. However, he was quite glad because Edmund and Lucy were coming to stay. Because Edmund and Lucy were slightly the same age with him. He liked bossing and bullying by his words. He believed that he could treat them that way because they stayed in his house and it was his own territory. He had the power and he was a winner. The annoy acted by Eustace was stated on following passage,

"For deep down inside him he liked bossing and bullying; and, though he was a puny little person who couldn't have stood up even to Lucy, let alone Edmund, in a fight, he knew that there are dozens of ways to give people a bad time if you are in your own home and they are only visitors." (Lewis, 2014:9)

\section{b. Selfishness}

Selfish was the behavior of caring only about you rather than about other people (Oxford Dictionary, 2015). While the ship members were busy to collect some food and fixing the ship. Eustace was lying under the tree, suddenly he decided to silently leave them until the work was over. Eustace would like to enjoy his time in airy place in the mountain without needed to hard work and could simply come back if he felt better. He was just thinking about his own pleasure without cares about others. Moreover, it was not only a thought but it became the real action. Eustace left the ship's company without told anyone. His selfishness was stated in this following quote.

"As Eustace lay under a tree and heard all these plans being discussed his heart sank. Was there going to be no rest? It looked as if their first day on the longed-for land was going to be quite as hard work as a day at sea.
Then a delightful idea occurred to him. Nobody was looking-they were all chattering about their ship as if they actually liked the beastly thing. Why shouldn't he simply slip away? He would take a stroll inland, find a cool, airy place up in the mountains, have a good long sleep, and not rejoin the others until the day's work was over." (Lewis, 2014:150-151)

\section{c. Greediness}

Greed was a strong desire for more wealth, possession, and power (Oxford Dictionary, 2015). Eustace was trapped on the valley. It was no use trying to climb in the rain. He looking for shelter and he found a cave, but it was not only an ordinary cave, it was an advance treasure cave. He was not realized that it was not belong to him and he was taking that treasure greedily. He was fulfilling his pockets with diamond also the bracelet above his elbow. Eustace's greediness was stated on following pattern.

"With some of this stuff, I could have quite a decent time here-perhaps in Calormen. It sounds the least phoney of these countries. I wonder how much I can carry? That bracelet nowthose things in it are probably diamonds-I'll slip that on my own wrist. Too big, but not if I push it right up here above my elbow. Then fill my pockets with diamonds-that's easier than gold." (Lewis, 2014:167)

\section{The Implications of the Novel Good Values for Education}

Values are universal. In every part of the world, having a good values is the main objective of every human in the social life. The universalism of the values make them suitable for all human condition included education. If we talk about education in Indonesia, it must be considering to the Curriculum. 
The 2013 Curriculum is a unit to integrate Strengthening Character Education. The government want to focus education not only on knowledge and skills but also on the students' spiritual and social improvement as set out in the new 2013 Curriculum.

The Voyage and the Dawn Treader novel is a novel, which has many values which, was congruent with the 2013 Curriculum in the term of spiritual and social competencies. This novel has several good values which can be used as the teaching material and implicitly to teach about the spiritual and social competencies for the students as well.

\section{Discussion}

There were similiarities between this research catagorization and Stewig (1980) and Jinamez (2008) values catagorization. Those were integrity values, family value, religious value, and two social values. The integrity value according to Stewig (1980 whereas Jinamez (2008) named this value as personal values implied from obedience, honesty, imagination, pleasure, bravery, intelligence, forgiveness, annoyance, selfishness, and greediness. Family value which shown by Lucy character as kinship value Then, religious value was shown by Eustace as regret value. Moreover, social values also appeared from helpful and friendship.

While Rokeach (1973) classified values into two subs values, they were terminal values and instrumental values. There were several Rokeach's values that also found on The Voyage of the Dawn Treader novel such as pleasure as personal (self-focused) and friendship as social (focus on others) on terminal values. Whereas, imagination, bravery, and intelligence as competence on instrumental values. Moreover, forgiveness, honesty, helpfulness, and obedience were categorized as moral on instrumental values. Loving and caring on kinship value also can be categorized as moral on instrumental value.

On the other hand, among Jinamez, Rekeach, and Stewig do not mention about bad values. However, the researcher found several bad attitudes, which was shown by the characters of The Voyage of the Dawn Treader novel such as annoyance, selfishness, and greediness.

\section{CONCLUSION}

This study aimed to find out childhood good values of The Voyage of the Dawn Treader novel, which is presented by the children characters. They are Edmund, Lucy, and Eustace. This research also would like to find out the implications of childhood good values for education.

From the finding of the research, there are several childhood good values such as obedience, honesty, imagination, pleasure, kinship, bravery, regret, intelligence, helpfulness, forgiveness, and friendship. Moreover, there were very interesting things found on this novel, it is about the improvement character of Eustace which, before were very annoy, selfish, and greedy. The readers could take the message from those bad attitudes presented by Eustace.

This novel illustrated that there are always a bad consequences of bad behavior and we must pay what we have done as what Eustace had done. He was turn into a dragon until he was regret, trying to change into a good person, and asking for forgiveness. Magically, he was back into human and change into a good human. The improvement of Eustace character started from when he felt lonely and regret of what he had done.

Children literature provides many good lesson and values that can be taken by the reader. Values in The Voyage of the Dawn Treader novel are not only about moral, but also about family, friends, 
social, cultures, behavior and attitude. It was implied that values were very universal, it can help the implementation of the 2013 Curriculum in Indonesia as well. The teacher can used the values on the novel as the teaching material and source of references to teach the students about religious and social attitude and behavior which, had been mention on the basic competencies namely KI 1 (spiritual competency) and $\mathrm{KI} 2$ (social competency).

\section{SUGGESTIONS}

Based on the results and discussion of this research, there were some suggestions that the researcher intended to convey:

1. For those who are interested in analyzing values in the novel, they should search for the application of the values for education since the researcher only study about the implications.

2. For the academics field especially teachers who read the findings of this study, the researcher suggests them to educate the students with good values adapted in The Voyage of the Dawn Treader novel.

3. For the writer and author especially novelist in Indonesia, the researcher suggest to make novels which have children literature genre. It is rarely found novel for children since the most popular novel is teenager or adult genre.

4. For the readers, the researcher suggests to take all of the good values and lesson on every book they read.

\section{REFERENCES}

Arikunto, S. (1998). Prosedur Penelitian Suatu Pendekatan Praktek. Jakarta : PT. Rineka Cipta. Jakarta.

Creswell, John W. 2009. Research Design Third Edition. United States : SAGE Publications.
Fajar, Syamsul. 2017. Moral Values Analysis In The Rainbow Troops Novel Written By Andrea Hirata. Unpublished Thesis. Aceh : State Islamic University Ar-Raniry.

Hunt, Elgin F. and Colander, David C. 1984. Social Science an Introduction to the Study of Science. New York : Macmillan Publishing Company.

Jimenez, Juan Carlos. 2008. The Significance of Values in an Organization. Caracas : Cograf Comunicaciones.

Johnson, R, B., \& Larry B,C., 2004. Educational Research : Quantitative and Qualitative Approaches. Boston : Allyin \& Bacon.

Hornby, As. 2015. Oxford Advanced Learner's Dictionary. New York : Oxford University Press.

Oxford. 2018. Oxford Living Dictionary. Online Dictionary : Oxford University Press.

Stanton, R. 1965. An Introduction to Fiction. New York : University of Washington.

Stewig, John Warren. 1980. Children and Literature. USA : Houghton Mifflin Company.

Sugiyono. 2006. Metode Penelitian Kuantitaif, Kualitatif, dan $R \& D$. Bandung : Alfabeta.cv.

Tuulik, K., Tauno Õ., Karin K., \& Eneken T. 2016. Rokeach's instrumental and terminal values as descriptors of modern organisation values. International Journal of Organizational Leadership. 151-161.

Zuriah, Nurul. 2009. Metodologi Penelitian Sosial dan Pendidikan. Jakarta : PT Bumi Aksara. 